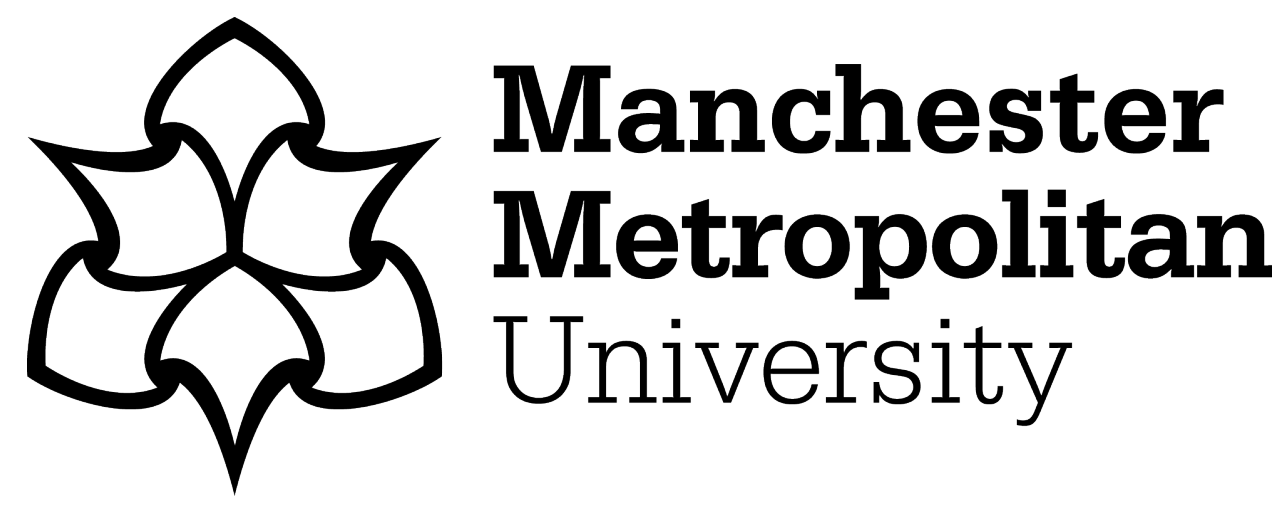

Coyle, T and Platt, LC (2018) Feminist Politics in the Festival Space. In: Routledge Handbook of Festivals. Routledge. ISBN 9781138735811 (In Press)

Downloaded from: https://e-space.mmu.ac.uk/619590/

Version: Accepted Version

Publisher: Routledge

Please cite the published version 


\section{Feminist Politics in the Festival Space}

Tasmin Coyle and Louise Platt

\section{INTRODUCTION}

Feminism in the context of festivals from a Western perspective has been examined across disciplines but rarely synthesized within the festival studies literature. Within the leisure studies literature, there has been a more substantive examination, and the distancing of 'event management' (within which festival studies often sits) as an area of study from leisure studies, we suggest, has led to a lack of engagement with this literature. For example, Aitchison's work $(1999,2000)$ is rarely drawn on in events (exceptions of work which cite these works include: Browne, 2009; Finkel and Matheson, 2015) and the work of Watson and Scraton (2011) on thinking intersectionally in leisure studies has only been cited in relation to sport rather than 'events management' explicitly. We contend that lack of engagement with these concepts is a missed opportunity in thinking critically about festivals in relation to intersectional feminism.

There is evidence of literature which examines gender performance within the festival space (for example Goulding and Saren, 2009) and experiences of women at greenfield festivals (Browne, 2009); however, this chapter addresses the role of feminist politics specifically in the production of festivals within the arts sector. This has been placed within the context of the 'wave narrative', the evolution of feminist politics and the influence that this has had on growing numbers of DIY arts festivals in urban locations. It offers critical case studies from an organiser perspective of festivals that put feminist politics to the fore.

\section{THE WAVE NARRATIVE: THE EVOLUTION OF FEMINIST POLITICS}

Whilst problematic, the wave narrative is used to define specific time periods of feminist activism and social change took place. Whilst scholars are dependent on the wave narrative to articulate the evolution of feminist thought, they are consciously critical of its usage, citing that the waves are generationally divisive. This section will briefly offer an overview of the wave narrative in order to place subsequent discussions in context. It is beyond the scope of this chapter to offer a comprehensive social and political history of feminist movements, but it is important to understand their contemporary relevance in order to analyse feminist festivals.

In summary, 'first wave' feminism refers to the period of the Woman Movement (Suffrage Movement) in the late 19th century to the early 20th century and campaigns for votes for women. 'Second wave' feminism (Women's Liberation Movement) is characterised as beginning in the 1960s influenced by the publication of the translation of Simone de Beauvoir's The Second Sex in 1953 and subsequent publication of The Feminist Mystique by Betty Friedman in 1963. This took place alongside events in the UK such as the introduction of the contraceptive pill in 1961, the strike of the machinists at the Ford factory in Dagenham in 1968, and the passing of the Sex Discrimination Act in 1975. Agreement over what equality was within this period are debated within the movement, and this period has come under criticism for treating women as a homogeneous group; indeed, a group which was white and 
relatively privileged. Therefore, a key aspect that distinguishes 'third wave' feminism is that of intersectionality (Evans, 2015). bell hook's seminal work Ain't I am Woman (1981) brought attention to the devaluation of black femininity within the movement. Further, queer theory defines this era with feminists working to break down gender binaries, such as Teresa de Lauretis (1991) who coined the term 'queer theory' and Judith Butler's Gender Trouble (first published in 1990). The 'third wave' has been criticised for a focus on individual emancipation and micro-politics that is by no means resolved within 'fourth wave' feminism; yet, the attention to intersectionality maintains a strong focus (Brown et al., 2017; Zimmerman, 2017).

Social media and online activism is often cited as the primary differential of the 'fourth wave' (Chamberlain, 2017) although there is contention over this, particularly in the UK context. In their work, Aune and Holyoak (2017) suggest that the third wave in the UK started much later than in the US, and the cultural and political particularities of the context within which feminist politics is being enacted need to be examined. They further suggest that the affordances new technologies offer (i.e. online activism) do not alone signal a new wave.

In the UK, there has been a renewal of interest in feminism amongst young people in the early 2000s. This media driven image is said to be undoing feminism. This neoliberal, post-feminist sensibility is subsumed into popular culture, 'as an identity that any young woman might like to have - it is stylish, defiant, funny, beautiful, confident, and it "champions" women' (Gill, 2016: 625). However, there is a danger that this critique of younger feminists renders their political activism invisible (Aune and Holyoak, 2017).

Nonetheless, social media allows women to organize activism; for example, the swift organization of 2011 'SlutWalk', a reaction to a police officer in Ontario, Canada, suggesting women should 'stop dressing like sluts' in order to avoid sexual harassment (for example: Borah and Nandi, 2012; Dow and Wood, 2014; McCormack and Prostran, 2012). Other campaigns include No More Page 3, calling for an end to use of topless models in British tabloid newspapers (Glozer et al., 2015), and the Twitter account (and subsequent book) Everyday Sexism, which encourages women to call out sexism in everyday rhetoric (Bates, 2016). More recently, debates around 'safe spaces,' 'trigger warnings,' and 'no-platforming' (Byron, 2017; Dunt, 2015; Lewis et al., 2015) have all played out on social media as well as issues of trans* identities (Jackson et al., 2017; Johnson, 2013).

What has also developed from this engagement in the online sphere is a "call out culture' (Cochrane, 2013), and the phrase 'privilege checking' has emerged. This encourages women to reflect on where their viewpoint stems from and to remember that all forms of feminisms are valid (see Freeman, 2013 for a summary of the emergence of the term). Further, the online environment can be viewed as facilitating intersectionality, as it allows women from different communities, ethnicities, and backgrounds to engage in conversation with each other (Chamberlain, 2017; Cochrane, 2013; Dobson, 2016). Yet, the anonymous nature and relative freedom of the internet now opens women to backlash, often in the form of threats of physical violence and sexual abuse (Baer, 2016; Eckert, 2017; Jane, 2014). 
Therefore, in summary, the wave narrative is helpful in understanding the evolution of contemporary feminist politics. Whilst contentious and often culturally specific, there is however, a call to reframe the narrative to be more nuanced in order to avoid a privileging of one particular cultural perspective.

\section{FESTIVALISING FEMINISM}

It is generally accepted that one of the roles of festivals is to provide an opportunity for catharsis (Bennett et al., 2016). Using festivity to champion a particular political viewpoint or as an act of collective activism is nothing new. Most notable examples are Pride parades which are not only a celebration of LGBTQ identities, but also emerged in the 1970s in the US as a 'liberation march' in commemoration of the Stonewall Riots (Browne, 2007; Johnston, 2007; Johnston and Waitt, 2015). Further to this, there is a strong historical link between music festivals and political activism from the 1960s onwards (Martin, 2016; McKay, 2004, 2015; Partridge, 2006). In July 2017, the leader of the UK Labour Party, Jeremy Corbyn, spoke at Glastonbury Festival. These are examples of 'civil leisure' (Mair, 2002) and using festivity to engender social change is emerging as a field of interest for event scholars (de Jong, 2017; Lamond and Spracklen, 2014; Sharpe, 2008).

Whilst festivals have always had elements of pleasure, the emphasis on political activism perhaps has diminished and are increasingly becoming commercialized and sanitized for the purpose of the enhancing the visitor experience (Anderton, 2008) or utilised in destination marketing (Quinn, 2010). It can be argued that we are seeing a festivalisation of feminism, which could potentially be critiqued as an example of the post-feminist sensibility where activism has been subsumed into the entertainment industry. However, it is important to view feminist festivals with critical lens, one that can leave space for a critique of neoliberal post-feminism without making collective feminist activism invisible or reduced to a mere fashion trend.

\section{Festivals as spaces for women}

Festivals have the potential to provide spaces for women to gather as a collective. Feminist geographers have reminded us that when we think about spaces, they cannot be thought of as neutral (Massey, 2013; Rose, 1993). Leisure spaces have been examined in relation to gender and sexuality (Aitchison, 1999; Scraton and Watson, 1998 ) with fear and apprehension of risk as a common mechanism of women's selfexclusion from public spaces.

In relation to specific festivals related to feminism and women, there is an uneasy relationship with public spaces; however, solutions are often problematic. An example widely examined in academic literature is Michigan Womyn's Festival (or Michfest) which grew out of the lesbian feminist movement in the 1970s US. The festival had a strict 'womyn born womyn's space' policy which was challenged by those who claimed the policy was discriminatory. Whilst the inclusion/exclusion of transgender women in this festival was complex (see Gamson 1997 and McConnell, Odahl-Ruhn et al 2016 for an in-depth discussion), it was identified by Browne (2011) that longstanding, dedicated festival-goers even also criticised cisgender attendees as 'weekend converts,' casting doubts on their lesbian feminist politics. As previously discussed with the wave narrative, generational divisions emerge. The boundaries of 'woman' 
'feminist' and 'lesbian' are negotiated in this space, and intersectional diversity comes under the microscope. As McConnell et al (2016) argue, there is a danger that a dominant intersectional identity (in the case of Michfest - cisgender, white, lesbian, feminist) can lead to further separatist spaces and reflect oppressive systems the festival is seeking to counteract. Also, whilst the temporal festival space can be problematic in issues of inclusion/exclusion, it is also possible, as indicated above, that that this temporal space could also mean only temporal engagement. The eventual demise of Michfest also exemplifies the evolution of feminist politics and its role within the rise and fall of festival trends.

Festival spaces can be spaces of risk for women; for example, there is an increasing number of sexual assaults at British greenfield festivals. Following the rape of a festival-goer at Latitude festival in 2010 Melvyn Benn, the chief executive of Festival Republic (Topping, 2010) released a statement:

[...] When you go to a festival with your friends and you drop your guard, but you are living in what is essentially a small town, and in a town you wouldn't leave your door open without expecting some crime.

This is the familiar territory of 'victim blaming' - a key issue that has been raised on social media by contemporary feminists and echoes the 'Slut Walk' movement discussed above.

Festivals have experimented with so-called 'safe spaces', a notion that is tied up with contemporary feminism despite origins in 1970s US. The production of The Sisterhood, Glastonbury's women only space in the area of Shangri-La is described on Twitter as, '[...] Glastonbury's first ever women only venue! Intersectional, Queer, Trans \& Disability inclusive.' Whilst more inclusive than Michfest, it saw a backlash from women in the UK conservative press who believed it to be a patronizing gesture (Whelan, 2016). Indeed, just because a space is designated as a women-only space does not guarantee safety (Lewis et al., 2015). Yet, as an article in Vice Magazine's online music site Noisey pointed out:

It's not as if all the women at Glastonbury are getting together to hurl all the men on a bonfire in the stone circle at dawn in a mass sacrifice, with Emily Eavis at the front chanting "Safe space! Safe space! Safe Space!" It is just a tent for women to hang out, dance and get drunk in. It's that simple - and that's why it works. (Jones, 2016).

The 'outcry' in relation to this space is an example of the prominence of highly mediated debates related to the role of online interactions in feminist politics today.

The festival space also can provide a platform for women as artists. Although women make up most of the creative workforce, they are under represented at the top levels and on boards. This has led to women creating their own DIY spaces. For example, the Riot Grrrl movement encouraged female punk bands, self-publishing zines, and knowledge sharing amongst women. This ethos was born out of necessity and a reaction to industries that ignored women and will be evidenced in the discussions of the festival case studies below. 


\section{CRITICAL CASE STUDIES}

The chapter will now proceed to present illustrative critical case studies of UK festivals which place feminist politics to the fore. These festivals are arts-led festivals that take place in the urban environment (as opposed to greenfield festivals). The festivals (and the participants) have been anonymised for confidentiality. All four case studies are small-scale and voluntarily run by creative women emerging from a DIY ethos. The following discussion draws on semi-structured interviews with four festival organisers and illustrates the role that feminist festivals are playing in activism, and the challenges that they face as part of negotiating the evolution of feminist politics.

\section{Festivals as Platforms for Feminist Politics}

Participants all suggested that their festivals were a platform for feminist politics but they expressed concern over the usage of the wave narrative. One interviewee stated, 'I think the Wave metaphor isn't really helpful because it kind of presupposes there's this distinction across the generations and actually that's not really true.' Further, it was agreed that the wave metaphor is problematic in moving feminism forward due to the lack of communication across generations of feminism; 'there is an issue here around, around inter-generational communication between different levels, or different generations of feminists' (Festival A). This reinforces the arguments made above that a more nuanced approached to the wave narrative needs to be taken.

When asked if the different forms within feminist ideology have ever posed a challenge in the organisation of the festivals, one participant responded:

In the early stages, we found there was two different ideas of what feminism is about and what [festival] could do. So one natural division kind of happened between one kind of perspective of feminism which was a little bit more exclusionary than we were wanting to go with. (Festival B).

Another participant shared that their organisation remains open to displaying different ideas about feminism without 'eating itself up' (Festival A) and stated that the divisions within feminism are hindering the feminist movement. These participants clearly expressed a more inclusive and intersectional view of feminist politics within their organisation, which is typical of the third and fourth wave movements. Whilst the four festivals had different ideologies across their organisations and found the wave narrative problematic, it was found that having a clear vision of what feminism meant to them was integral to the success of the festival.

Further, all participants viewed their festivals as a potential catalyst for their audiences to become more engaged in feminist politics:

Our thinking is that you don't go from your sofa to the picket line in one fell swoop, you have to have those interactions along the way and that's what we're trying to do, is be something which doesn't feel really overwhelming and academic or like elitist or exclusive. (Festival A).

Helping women become more confident in engaging in both feminist politics and politics in general is something all participants agreed on. These festivals could potentially provide women with an accessible introduction to politics. There is the 
danger however, like MichFest, that 'versions' of feminist politics can become outmoded and fall out of favour, challenging the sustainability of such festivals.

There was an acknowledgement of the increased popularity of feminism, and it was felt that a post-feminist sensibility was an opening to develop meaningful discussions about activism in the festival space:

Suddenly every pop star was like, I'm a feminist. And it did maybe feel a little motivated by something that wasn't quite feminist, but at the same time like that is exposing loads of young girls who've never heard that word to the word feminist, that'll hopefully go and Google it and find out like what it actually is. (Festival A).

However, there was a more critical view which could present a challenge in maintaining political relevance of the festivals, especially in light of individualistic narratives of feminism:

I sometimes go to things and I talk to younger generations of feminists, you know it seems to be they're only engaged with a very tiny aspect of what affects them personally. There's a lack of global awareness, there's a lack of international perspective. (Festival C).

There was evidently a challenge in engaging new audiences. Social media provided a platform, but it had to then translate into physical spaces:

I think we've managed to build this community which very much does exist online but also translates to the real world and kind of like the vibe that we're giving off online... I think that's something that we're really conscious of ... we don't just want to be another social platform sharing inspirational memes. (Festival A).

Taking the example of the Slut Walk mentioned previously, this campaign may have mobilised online; however, it was only able to deliver an impact once it manifested in a physical space. Therefore, festivals offer the opportunity to blur the online/offline activism spaces and further challenge the distinction of 'fourth wave' being defined by online activism or indeed the existence of this wave at all.

\section{Feminists Festivals as Space of Empowerment}

When asked if feminist festivals could provide a solution for women to safely engage in the festival scene, participants were keen to stress that what they can offer is an 'add on', not a solution due to the temporality of the festival format.

Feminist festivals are not a substitute for, they're an addition to. And it's really important to make sure that is your aim, it's like this is just one aspect where you can talk about issues where you can kind of maybe come up with a plan. (Festival B).

It is also possible that feminist festivals can offer women support in their creative practice. One festival organiser commented that: 
Learning how to design your own flyers and to do decent social media marketing and to write a good press release and empower yourself to be able to know how to run your own tech, all those skills are really important to then be able to produce and run your own shows and therefore be a more successful artist. And they're the kind of things that we try and offer within the Festival, but we are limited at capacity. (Festival D).

This supportive and DIY ethos was something that all participants interviewed commented on and stated was deeply ingrained in their festivals ethos. This DIY style is reminiscent of the third wave feminist movements, empowering each other to take control in a male dominated industry. Since there is still a serious inequality issue in the creative industries, this DIY ethos is still driving feminist creative as a collective.

I think feminist festivals have had to fight really hard because those positions, [...] we've had to prove that we can do it and then also we end up doing it 20 times better because we're working harder. (Festival B).

Whilst these festivals offer a supportive environment they were mindful of their capacity to pay.

There's always a debate, an issue around payments of performers and payment of participants, and that is a feminist issue as far as I'm concerned because there's so much expected as goodwill from participants, particularly women and women are always underpaid, or not paid. (Festival C).

Whilst these festivals can form a supportive community for women artists, due to their lack of funding, there is an issue with the fair payment of artists. Again, this tension emerges around a DIY ethos, but it creates limitations around being financially sustainable.

\section{Festivalisation of Feminism}

Wider institutions potentially take advantage of feminist festivals for their own marketing gains, and there is perhaps a festivalisation of feminist politics to serve a particular agenda. At least two of the festivals noted that established institutions were starting to approach them with collaboration opportunities. However, they were both cautious when choosing who to work with in order to maintain their DIY ethos.

I think we're going to have to be quite careful about how we negotiate that... but often what venues want to do is basically tap into your audience and be like, oh you've got loads of like women under 30. (Festival A).

Some expressed frustration related to International Women's Day, 'everybody is like Rent a Feminist for the month because its International Women's Day in March' (Festival A). The trend for feminist politics, as examined above, can make activism less visible, and it is important that these festivals maintain a balance between establishing a profile for what they do, which might mean collaborating on national events or with wider institutions, but ensure that the politics remain meaningful. 
In order to achieve this, there was an awareness that organisers had to engage with audiences outside of themselves and existing feminist activists. If the festivals are unable to engage with wider audiences, it becomes difficult to establish to what extent they are achieving bringing communities together and translating the temporal space of the festivals into activism and social change. 'It was showcasing some sort of feminist work that's taking place but it didn't really connect with audiences outside of itself' (Festival C).

\section{CONCLUSIONS}

The four festivals examined in this chapter are helping women become more confident in engaging in both feminist politics and general politics by providing them with an accessible introduction to politics. There is also a deliberate effort to engage with popular culture but not to allow the collective aspect of feminist activism to be diminished. Indeed, the power that the online sphere offered was recognized but, the interaction of festival-goers in physical spaces is still salient. This is all the more true in relation to festivals that intend to inspire social change and collective action. However, there needs to be further consideration around how to make the physical spaces of such festivals as accessible as online spaces in terms of collective activism (whilst acknowledging debates around online access).

Aligned with the contentious nature of the wave narrative, feminists who are organising these festivals are conscious of what feminism means to different audiences and how they can present bring younger women into activism. A continued engagement with the wave narrative as affective rather than hierarchical is essential in order to create inclusive spaces that are relevant and sustainable, and able to respond to the changing and evolving nature of politics today without forgetting the activism of those that came before or diminishing the lived experiences of diverse groups of women.

There is rich potential for further study in this area, not least as the work presented here is solely offered from an organiser perspective. Further research could focus on how feminist festivals are spaces where multiple identities are negotiated. This would build on previous leisure studies work on intersectionality and further related critical festival studies under a critical feminist lens.

\section{REFERENCES}

Aitchison, C. (1999) New cultural geographies: the spatiality of leisure, gender and sexuality. Leisure Studies 18(1): 19-39.

Aitchison, C. (2000) Poststructural feminist theories of representing Others: a response to the 'crisis' in leisure studies' discourse. Leisure Studies 19(3): 127-144.

Anderton, C. (2008) Commercializing the carnivalesque: the V Festival and image/risk management. Event Management 12(1): 39-51.

Aune, K., \& Holyoak, R (2017) Navigating the third wave: Contemporary UK feminist activists and 'third-wave feminism'. Feminist Theory: 1464700117723593.

Baer, H. (2016) Redoing feminism: digital activism, body politics, and neoliberalism. Feminist Media Studies 16(1): 17-34. 
Bates, L. (2016) Everyday Sexism: The project that inspired a worldwide movement. London: Simon \& Schuster

Bennett A, Taylor J, and Woodward I (eds) (2016) The Festivalization of Culture, Oxon \& New York: Routledge

Borah, R. \& Nandi, S. (2012) Reclaiming the feminist politics of 'SlutWalk'. International Feminist Journal of Politics 14(3): 415-421.

Brown, M., Ray, R., Summers, E. \& Fraistat, N. (2017) \# SayHerName: a case study of intersectional social media activism. Ethnic and Racial Studies 40(11): 1-15.

Browne, K. (2007) A party with politics? (Re)making LGBTQ Pride spaces in Dublin and Brighton. Social \& Cultural Geography 8(1): 63-87.

Browne, K. (2009) Naked and dirty: rethinking (not) attending festivals. Journal of Tourism and Cultural Change 7(2): 115-132.

Browne, K. (2011) Beyond rural idylls: Imperfect lesbian utopias at Michigan Womyn's music festival. Journal of Rural Studies 27(1): 13-23.

Butler, J. (1990) Gender Trouble. New York: Routledge

Byron, K. (2017) From infantilizing to world making: Safe spaces and trigger warnings on campus. Family Relations 66(1): 116-125.

Chamberlain, P. (2017) The Feminist Fourth Wave: Affective Temporality. New York: Springer.

Cochrane, K. (2013) All the rebel women: The rise of the fourth wave of feminism. London: Guardian Books.

de Jong, A. (2017) Rethinking activism: tourism, mobilities and emotion. Social \& Cultural Geography 18(6): 851-868.

De Lauretis, T. (1991) Queer theory: Lesbian and gay sexualities. Bloomington: Indiana University Press.

Dobson, A.S. (2016) Postfeminist digital cultures: Femininity, social media, and selfrepresentation. New York: Springer.

Dow, B.J. \& Wood, J.T. (2014) Repeating history and learning from it: What can SlutWalks teach us about feminism? Women's Studies in Communication 37(1): 2243.

Dunt, I. (2015) Safe space or free speech? The crisis around debate at UK universities. The Guardian, 6th February. Available from:

https://www.theguardian.com/education/2015/feb/06/safe-space-or-free-speech-crisisdebate-uk-universities (accessed 18 August 2017). 
Eckert, S. (2017) Fighting for recognition: Online abuse of women bloggers in Germany, Switzerland, the United Kingdom, and the United States. New Media \& Society OnlineFirst (doi 10.1177/1461444816688457)

Evans, E. (2015) The politics of third wave feminisms: Neoliberalism, intersectionality, and the state in Britain and the US. New York: Springer.

Finkel, R. \& Matheson, C. M. (2015) Landscape of commercial sex before the 2010 Vancouver Winter Games. Journal of Policy Research in Tourism, Leisure and Events 7(3): 251-265.

Freeman, H. (2013) Check your privilege! Whatever that means. The Guardian, 5th June. Available from: https://www.theguardian.com/society/2013/jun/05/check-yourprivilege-means (accessed 17 August 2017).

Gill, R. (2016) Post-postfeminism?: new feminist visibilities in postfeminist times. Feminist Media Studies 16(4): 610-630.

Glozer, S., McCarthy, L. \& Whelan, G. (2015) \# NoMorePage3: Feminism and institutional work in corporate constructed arenas of citizenship. In Academy of Management Proceedings January 2015(1): 16085

Goulding, C. \& Saren, M. (2009) Performing identity: an analysis of gender expressions at the Whitby goth festival. Consumption Markets \& Culture 12(1): 27 46.

hooks, b. (1981) Ain't I a Woman Black Women and Feminism. Boston: South End Press

Jackson, S.J., Bailey, M. \& Foucault Welles, B. (2017) \#GirlsLikeUs: Trans advocacy and community building online. New Media \& Society OnlineFirst (doi $10.1177 / 1461444817709276)$

Jane, E.A. (2014) 'Back to the kitchen, cunt': speaking the unspeakable about online misogyny. Continuum 28(4): 558-570.

Johnson, J.R. (2013) Cisgender privilege, intersectionality, and the criminalization of CeCe McDonald: Why intercultural communication needs transgender studies.

Journal of International and Intercultural Communication 6(2): 135-144.

Johnston, L. (2007) Mobilizing pride/shame: lesbians, tourism and parades. Social \& Cultural Geography 8(1): 29-45.

Johnston, L. \& Waitt, G. (2015) The spatial politics of gay pride parades and festivals: Emotional activism. In: Patternotte, D. \& Tremblay, M. (eds) The Ashgate Research Companion to Lesbian and Gay Activism, Surrey \& Burlington: Ashgate, pp. 105120.

Jones, D. (2016) Do we need a women's only venue at Glastonbury? Noisey. Available from: https://noisey.vice.com/en_uk/article/6e4e3k/do-we-need-a-womensonly-venue-at-glastonbury (accessed 18 January 2017). 
Lamond, I.R. \& Spracklen, K. (2014) Protests as events: Politics, activism and leisure. London: Pickering \& Chatto Publishers.

Lewis, R., Sharp, E., Remnant, J. \& Redpath, R.. (2015) 'Safe Spaces': Experiences of feminist women-only space. Sociological Research Online 20(4): 9.

Mair, H. (2002) Civil leisure? Exploring the relationship between leisure, activism and social change. Leisure/Loisir 27(3-4): 213-237.

Martin, G. (2016) The politics, pleasure and performance of new age travellers, ravers and anti-road protestors: Connecting festivals, carnival and new social movements. In: Bennett A, Taylor J, and Woodward I (eds), The Festivalization of Culture, Oxon \& New York: Routledge, pp. 87-106.

Massey, D. (2013) Space, place and gender. Oxford: John Wiley \& Sons.

McConnell, E.A., Todd, N.R., Odahl-Ruan, C. \& Shattell, M. (2016) Complicating counterspaces: Intersectionality and the Michigan Womyn's Music Festival. American Journal of Community Psychology 57(3-4): 473-488.

McCormack, C. \& Prostran, N. (2012) Asking for it. International Feminist Journal of Politics 14(3): 410-414.

McKay, G. (2004) 'Unsafe things like youth and jazz': Beaulieu jazz festivals (195661), and the origins of pop festival culture in Britain. In: Bennett A (ed.), Remembering Woodstock, Aldershot: Ashgate Publishing, pp. 90-110.

McKay, G. (2015) The pop festival: history, music, media, culture. New York: Bloomsbury Publishing USA.

Partridge, C. (2006) The spiritual and the revolutionary: Alternative spirituality, British free festivals, and the emergence of rave culture. Culture and Religion 7(1): $41-60$.

Quinn, B. (2010) Arts festivals, urban tourism and cultural policy. Journal of Policy Research in Tourism, Leisure and Events 2(3): 264-279.

Rose, G. (1993) Feminism \& geography: The limits of geographical knowledge. Minneapolis: University of Minnesota Press.

Scraton, S. \& Watson, B. (1998) Gendered cities: women and public leisure space in the 'postmodern city'. Leisure Studies 17(2): 123-137.

Sharpe, E.K. (2008) Festivals and social change: Intersections of pleasure and politics at a community music festival. Leisure Sciences 30(3): 217-234.

Topping, A. (2010) Rapes at Latitude prompt launch of safety awareness campaigns. The Guardian. Available from: https://www.theguardian.com/culture/2010/jul/19/latitude-festival-safety-campaign (accessed 24 June 2017) 
Watson, B. \& Scraton, S.J. (2013) Leisure studies and intersectionality. Leisure Studies 32(1): 35-47.

Whelan, E. (2016) Glastonbury's 'women-only' venue deserves to sink into the mud. The Spectator, 6th June. Available from:

https://blogs.spectator.co.uk/2016/06/glastonburys-women-venue-deserves-sink-mud/ (accessed 18 August 2017).

Zimmerman, T. (2017) \#Intersectionality: The fourth wave feminist Twitter community. Atlantis: Critical Studies in Gender, Culture \& Social Justice 38(1): 5470 . 